Article

\title{
Empowering People-Democratising the Food System? Exploring the Democratic Potential of Food-Related Empowerment Forms
}

\author{
Basil Bornemann ${ }^{1, *}$ and Sabine Weiland ${ }^{2}$ \\ ${ }^{1}$ Sustainability Research Group, Department of Social Sciences, University of Basel, 4051 Basel, Switzerland; \\ E-Mail: basil.bornemann@unibas.ch \\ ${ }^{2}$ European School of Political and Social Sciences, Université Catholique de Lille, 59016 Lille Cedex, France; \\ E-Mail: sabine.weiland@univ-catholille.fr \\ * Corresponding author
}

Submitted: 11 April 2019 | Accepted: 5 August 2019 | Published: 28 October 2019

\begin{abstract}
The current food system, characterised by considerable concentrations of economic and political power, is widely regarded as undemocratic and in many respects unsustainable in its outcomes. To address the democratic deficits in the food system, empowerment has become a central claim and point of reference for actors seeking to transform the system. In fact, numerous venues and practices have emerged in recent years to develop people's capacities to engage with food issues. These range from local food initiatives and health-food movements to food policy councils and government education policies. This article takes a closer look at the theory and practice of democratic empowerment in the food system. It explores whether and how different forms of food-related empowerment have the potential to improve the democratic quality of the food system. Based on a broad analytical understanding of empowerment that is combined with a notion of powerbased complex democracy, it is argued that different forms of food-related empowerment promote the development of different types of power, which in turn are constitutive for different functions of the democratic process. From this perspective, the challenge of democratising the food system lies in linking different complementary empowerment practices into functioning configurations of complex democratic governance.
\end{abstract}

\section{Keywords}

complex democracy; empowerment; food democracy; food policy; food policy councils; government food education; local food movements; plant-based diet

\section{Issue}

This article is part of the issue "New Perspectives on Food Democracy" edited by Basil Bornemann (University of Basel, Switzerland) and Sabine Weiland (Université Catholique de Lille, France).

(C) 2019 by the authors; licensee Cogitatio (Lisbon, Portugal). This article is licensed under a Creative Commons Attribution 4.0 International License (CC BY).

\section{Introduction}

Over the past decades, food production and consumption have become increasingly globalised and interconnected. Today we speak of a 'global' food system, spanning a plurality of territorially and functionally distinct food systems. While the global food system is providing more food than ever before in human history, it is increasingly subject to criticism. Hunger and undernutrition continue to plague the Global South, while, conversely, obesity and malnutrition are emerging chal- lenges in various regions, including Western industrial societies (International Food Policy Research Institute, 2016). In addition, the complex ecological and social problems of the modern food system are under discussion (Lang, Barling, \& Caraher, 2012).

The driving forces behind food system problems are manifold and multi-layered. They range from global environmental change to international market and governance failures to regional shifts in eating habits to local conflicts. From a critical perspective, however, the massive concentration of economic and political power 
in today's food system is a significant problem. Few companies hold high market shares in meat, seeds, agrochemicals, food processing and retail (Lang et al., 2012; McMichael, 2013). The concentration of economic power in turn reflects the political power structures shaping the food system. For a long time, foodrelated policies in Europe and North America have been crafted in relatively closed agro-political circles shielded from public attention and discourse (Skogstad, 1998; Tracy, 1989), recent developments in the direction of a post-exceptionalist and more open agricultural policy sector notwithstanding (Daugbjerg \& Feindt, 2017). Furthermore, policy-makers have entirely refrained from intervening in the food system altogether, often in the name of consumer rights and freedom of choice (Korthals, 2001). In this situation, how can the challenge of a concentrated, arguably undemocratic and largely unsustainable food system be met?

A common answer to this and similar questions in the political and scientific discourse is 'by empowering people.' Control of the food system, the argument goes, must be given to the people by improving their capability to decide on food-related issues more autonomously. The hope is that empowerment increases the participation and decision-making power of citizens and may potentially lead to transformative action which will change opportunity structures in an inclusive and equalising direction' (Andersen \& Siim, 2004, p. 2). Empowerment is thus seen as contributing to a more democratic and sustainable food system (Fernandez-Wulff, 2019; Hassanein, 2003; Lacy, 2000; Petetin, 2016). In practice, we can see that empowerment has become a central claim and reference point for various actors and their actions to transform the existing food system (Moore \& Swisher, 2015; Renting, Schermer, \& Rossi, 2012). A multitude of venues and practices have emerged in the food system to develop people's capacities for dealing with food issues and change existing food systems. These range from local food initiatives and health-food movements to institutionalised food policy councils and government education policies.

In this article, we examine the relationship between empowerment and democracy in theoretical and empirical terms. We share the common view that empowerment may be key to democratise the food system. However, given the diversity of venues for empowering people on food issues, it remains an open question whether all these venues have the same potential to improve the democratic quality of food systems. This question is all the more important since the supposedly simple relationship between empowerment and democracy has arguably become more complex in advanced Western liberal democracies. While empowerment in the 1970s and 1980s was seen, mainly by proponents of participatory democracy, as a promising approach to the democratisation of liberal democracy (Barber, 1984), both the practice and the debate have changed. On the one hand, the institutional practice of liberal democ- racies has undergone major changes, recently referred to as post-liberalisation, i.e., a decentring and pluralisation of democratic institutions and practices (Sørensen \& Torfing, 2005). On the other hand, the concepts and criteria for describing and assessing democracies in increasingly layered and pluralised governance settings have become more varied and complex (Schmidt, 2013). If the democratic quality of empowerment is to be evaluated under the conditions of contemporary post-liberal and complex democracy, a re-examination of the conceptual relationship between empowerment and democracy is necessary.

Against this backdrop, we ask in this article: What is the democratic potential of different food-related empowerment forms? To answer this question, we provide a novel theoretical conceptualisation of democratic empowerment that combines a broad analytical understanding of empowerment with a concept of powerbased complex democracy. On this basis, we offer tentative empirical interpretations of the democratising potential of various forms of food-related empowerment that can be found, especially in the context of Western liberal democracies, in four different types of venues for involving people in food issues.

We develop our argument as follows: In Section 2, we conceptualise empowerment as an analytical perspective composed of several dimensions and reflect on its relation to democracy. Doing so leads to a differentiated conceptual understanding of democratic empowerment. In Section 3, we interpret existing research on four typical venues where people get involved in food issues from an empowerment perspective, drawing a more differentiated picture of food-related empowerment practices in these venues. Section 4 discusses the democratic implications of these different forms of food-related empowerment. In the conclusion, we reflect upon future research on food-related empowerment as a viable strategy for the transformation of the food system.

\section{Empowerment and Democracy: A Conceptual Framework}

The concept of empowerment is used in different practical and disciplinary contexts (psychology, education, politics) with different meanings (McLaughlin, 2016). Generally speaking, empowerment refers to practices of engaging people and bringing them into positions of agency to articulate their concerns regarding individual or societal goals. Amy Allen (1998), in her account of political empowerment, developed a relational understanding in view of a differentiated concept of power. For her, empowerment is a counter-movement to classical manifestations of 'power over,' understood as the 'ability of an actor...to constrain the choices available to another actor' (Allen, 1998, p. 33). Empowerment, in contrast, refers to a different form of power, called 'power to,' described as the 'capacity of an agent to act in spite of or in response to the power wielded over her by oth- 
ers' and to the 'ability of an individual actor to attain an end or series of ends' (Allen, 1998, p. 34). Such a concept is committed to an emancipatory goal: The development of a kind of counter-power that liberates individuals from domination ('power over') by bringing them into positions of agency ('power to'). It should be noted that empowerment as emancipation is a self-induced, autonomous process. People cannot be empowered by others; they can only empower themselves (for a discussion, see McLaughlin, 2016, pp. 38-51).

\subsection{Dimensions of Empowerment}

This rather narrow, normative conception of empowerment stands in contrast to a broader and more analytical use of the term, which refers to various practices by which people actively or passively attain positions of relative power of different kinds (Avelino, 2017). In this article, we use such a broad analytical approach because it allows us to capture the diverse landscape of empowerment forms that can be found in different venues for involving people in food issues. To grasp these forms in a detailed manner, we propose a set of analytical dimensions that frequently appear in the broader empowerment discourse (e.g., Andersen \& Siim, 2004; Avelino, 2017; McLaughlin, 2016). These dimensions correspond with a series of conceptual questions to which each empowerment practice relates in some way: Who empowers whom, how, where, and to what ends?

The first dimension refers to the empowerment $a c$ tors. Following a broad analytical understanding, the related question 'who empowers whom?' can be answered in two distinct ways. Empowerment can be understood either as a social act between two actors, i.e., an actor (subject) who empowers another actor (object), or, in an emancipatory perspective, as an autonomous act of selfempowerment of a single actor. While, in principle, different kinds of actors can be involved in empowerment processes, it is important to distinguish between individual and collective empowerment. Empowerment can be understood as an act carried out by individual actors. But we may also think of empowerment as a form of collective action that 'encourages its participants to engage in dialogue with the aim of connecting their personal life experience to broader social-structural phenomena such as relations of oppression and domination, economic structures, cultural forms, and so on' (Allen, 2008, p. 167).

Asking the question of 'how?', the second dimension refers to the concrete means of empowerment. Depending on the context of action, we can discern a large diversity of specific empowerment means, each of which refers to different kinds of resources that bring people into positions of agency, including different forms of knowledge and different kinds of actions, through which people acquire power (such as education, participation, disobedience, contestation, subversion, deliberation, collaboration, etc.; for different strategies of foodrelated empowerment, see, e.g., Tornaghi, 2017).
The third dimension addresses the 'where?' question and refers to the context of empowerment. While there are many different venues for (political) empowerment (e.g., various political arenas, institutional settings and levels of governance), a more fundamental distinction in empowerment thinking can be described as 'inside vs. outside the system.' This distinction reflects the fact that actors either seek to attain power by raising their 'voice' from within a given system, or they address change from the outside based on an 'exit' approach (Sørensen, 1997). Sometimes, the contexts of empowerment become means for power contestations; for example, when established institutions seek to co-opt and internalise empowerment actors (Young, 1990, p. 90) or push them outside of the system by calling into question their legitimacy (Bornemann, 2017).

The fourth dimension addresses the question 'to what ends?' and captures the goal of empowerment. There are again many different issue-specific interpretations of empowerment goals (e.g., individual freedom, health, happiness). Yet, in view of our broad analytical understanding of empowerment as a process aimed at the development of power, the goal dimension can be related to different types of power envisaged by empowerment practices. While empowerment as developing power in the sense of 'power to' represents the classical emancipatory understanding, which is about challenging existing power structures and promoting alternatives, empowerment can also relate to other types of power. It can involve the creation of collective power that binds people together or enables them to 'act together for the attainment of a common or shared end or series of ends' (Allen, 1998, p. 35; see also Partzsch, 2017). This type of 'power with,' in Allen's terminology, is also referred to as 'generative' power (see Hendriks, 2009). Finally, the objective of empowerment may be the realisation of 'power over.' Although such an understanding clearly conflicts with the narrow emancipatory conception of empowerment, it seems relevant in the context of liberal-representative democracy. With its clear distinction between 'government' and 'the people,' such a model depends on the realisation of 'power over' in two respects. On the one hand, empowerment in the sense of the realisation of 'power over' refers to the government's ability to exercise political power, i.e., an institutionally 'caged' form of power as opposed to nonpolitical coercive power (see Haugaard, 2010). On the other hand, it refers to the people's ability to recognize 'power over' by the government as a legitimate form of political power.

\subsection{Democratic Implications of Empowerment}

Following these distinctions, empowerment is a multifaceted concept that refers to a variety of manifestations. But how does the concept and its interpetations relate to democracy? There exist many theoretical and empirical links between empowerment and democracy. From 
a historical perspective, Welzel (2013) regards empowerment as the main driving force behind democratisation, as opposed to elite strategies of democratisation. In the context of modern democratic theory, empowerment is discussed as an important prerequisite of the democratic process in that it aims to strengthen people's ability to participate in collective decisions through voice or vote (Sørensen, 1997). Not surprisingly, empowerment plays an important role in theories of participative or 'strong' democracy, according to which the democratic ideal of political equality is realised through maximised participation of the people (Barber, 1984). While the link between emancipatory empowerment and participatory democracy is certainly the most established, an analytical understanding of empowerment entails further connections to normative democracy theory. Deliberative or discursive theories of democracy, for example, can be associated with empowerment in the sense of developing 'power with,' as these notions of democracy presuppose collaboration and communication among basically equal actors (Dryzek, 2000; Hendriks, 2009). Ideals of pluralist, representative and liberal democracy, in turn, seem to focus on 'power over,' as the very idea is to establish processes that enable actors to exercise power over each other without domination (Haugaard, 2010, 2015).

Generally speaking, democracy and empowerment are thus linked by the concept of political power. Democracy, on the one hand, is the exercise of political power by the sovereign people (Mouffe, 2000). It describes a form of institutionalised acquisition, sharing and execution of political power (Haugaard, 2010): A way of managing societal conflict and solving common problems based on the use of (different forms of) political power, seeking to alter and, in view of an ideal of political equality, ultimately level political power relations (Beitz, 1989). Empowerment, on the other hand, refers to the process of attaining political power and can thus be conceived as a pre-condition or enabling force of the democratic process. It is concerned with the development of different forms of political power that, in turn, are related to different democratic principles, such as participation ('power to'), deliberation ('power with') and representation ('power over'). Thus, empowerment is not as such democratic; rather, empowerment is a process of power generation that creates the conditions for democracy.

Drawing on system-theoretical democratic thinking (Schmidt, 2013), these principles and related types of power can be interpreted as referring to three basic functions of a power-based concept of complex democracy, each linked with a certain type of empowerment (for a theoretical contextualisation, see Bornemann \& Haus, 2017; for an alternative interpretation of food democracy along the three dimensions of democratic legitimacy, see Behringer \& Feindt, 2019):

(1) On the input side, the democratic process involves opening or breaking an established political order by, for example, challenging the order and promoting alternatives. Doing so requires the development of 'power to';

(2) The throughput function of the democratic process consists of balancing or reshuffling existing power relations by, for example, developing actor coalitions or coordinating strategies, which require the development of 'power with';

(3) The output dimension of the democratic process involves the (temporary) closure of the previously opened and reshuffled political order in order to enable the implementation of collectively binding decisions. This requires empowerment geared towards the development of 'power over,' which refers to the ability to recognise and follow collective decisions (see Table 1).

Such a power-based understanding of complex democracy puts into perspective the widespread idea that especially emancipatory empowerment forms (in the sense of 'empowering to') exhibit a democratic potential. It is also critical of the common view that 'power over' necessarily represents an undemocratic form of power. Instead, it is based on the argument that democracy involves a complex regime of different power types and related forms of empowerment. 'Empowering to' is indeed essential to the democratic process. From the point of view of a complex democracy, however, it is only one element that must be supplemented, on the one hand, by 'empowerment with' in order to enable cooperation between actors, and, on the other hand, by forms of 'empowerment over' to allow for the implementation of collective decisions in a commonly binding manner.

In the remainder of this article, we use these conceptual considerations to analyse the democratic implications of different forms of food-related empowerment.

Table 1. Three dimensions of a power-based concept of complex democracy.

\begin{tabular}{lccc}
\hline & $\begin{array}{c}\text { (1) Input } \\
\text { 'Opening up' }\end{array}$ & $\begin{array}{c}\text { (2) Throughput } \\
\text { 'Balancing out' }\end{array}$ & $\begin{array}{c}\text { (3) Output } \\
\text { 'Closing down' }\end{array}$ \\
\hline Required type of power & Power to & Power with & Power over \\
\hline Empowerment as & $\begin{array}{c}\text { Challenging an existing } \\
\text { order by developing the ability } \\
\text { to promote alternatives }\end{array}$ & $\begin{array}{c}\text { Reshuffling an existing } \\
\text { order by developing the } \\
\text { ability to collaborate }\end{array}$ & $\begin{array}{c}\text { Establishing (a new) political } \\
\text { order by generating the ability } \\
\text { to recognise collective action }\end{array}$ \\
\hline
\end{tabular}


In the next section, we draw on the first three dimensions of empowerment to examine and compare different forms of food-related empowerment, which can be found in different types of venues for involving people in food issues. In Section 4, we focus on the fourth analytical dimension of empowerment to clarify how different forms of food-related empowerment promote the three types of political 'power to,' 'power with,' and 'power over' that are associated with the concept of powerbased complex democracy.

\section{Forms of Food-Related Empowerment}

In the course of a general process of politicisation, broadly understood as the expansion and intensification of political contestation in hitherto non-political areas, food has increasingly become a reference point in political debates as well as in individual and collective efforts to initiate processes of social transformation (Alkon \& Guthman, 2017). This is reflected in the rise of venues in which people become involved in practices of shaping and changing the way food is produced, distributed and consumed (Grauerholz \& Owens, 2015). Such practices range from the development of food-related knowledge and skills to become more self-determined vis-àvis food companies and caring more about one's own health to subversive direct interventions in the food system through urban gardening and practices of food rescue or food sharing; from the consideration of nutritional information and designations of origin in consumer decisions to more institutionalised political participation in food-related decision-making.

While the engagement of actors in different venues is driven by different, sometimes mixed and not always political concerns, the concept of empowerment appears to be an important reference point for both scientific observers and involved practitioners when it comes to determining the objective of these venues (Moore \& Swisher, 2015; Renting et al., 2012). Starting from this interpretation, we seek to draw a more differentiated picture of the forms of empowerment associated with these venues. Although our analysis is illustrative and preliminary rather than systematic, we focus on four venues typical of Western societies that bring with them a considerable variety of food-related empowerment forms. Our case selection includes two venues in which people become active from below by engaging in plant-based diets and local food initiatives, such as farmers' markets and community-supported agriculture (CSA). We also look at two more institutionalised venues for engagement in food policy councils, as well as in government food education programmes.

\subsection{Plant-Based Diets}

The first venue of food-related empowerment refers to plant-based nutrition practices, meaning that people exclude animal products, such as meat, dairy, eggs and animal by-products from their diets (Cherry, 2014). Over the past decade, the number of people living on a plant-based diet has multiplied, with growth rates of several hundred percent in some Western countries (Baum+Whiteman, 2018). Many people cite ethical reasons for not consuming animal products. The current food system is largely based on intensive livestock farming and production processes in which the treatment of animals at all stages of production has raised moral concerns (Grauerholz \& Owens, 2015). Plant-based diets are also claimed to have a wide range of health benefits, including lower cholesterol levels and a reduced risk of heart disease, hypertension, diabetes, obesity and cancer (Cherry, 2014). The standard American or European diet, which includes animal protein and large amounts of fatty and sugary food, is regarded as unhealthy and has been implicated in many lifestyle diseases in the industrialised world and beyond. Further, the negative environmental impact of meat and dairy production is tremendous, e.g., the production of greenhouse gases in the livestock industry (Grauerholz \& Owens, 2015).

The everyday practices of plant-based diet followers in Western societies largely consist of preparing vegan meals as alternatives to commodities derived from animals. Adopting this diet can be interpreted as empowerment insofar as its followers actively reflect on their eating habits and the welfare of animals and the environment, and acquire knowledge and skills that enable them to change their practices. Empowerment may at first result from an individual consumption decision and 'private' activity in people's kitchens, thus representing a form of self-empowerment. At the same time, a community exists to share experiences and tactics for a plantbased lifestyle and to encourage others to adopt that lifestyle. Today, community exchanges often occur via the internet and social networks. The number of vegan food blogs and YouTube channels is tremendous and continues to increase. In the real world as well, relevant infrastructure is growing, with cafés, restaurants, specialised supermarkets and other shops spreading in cities like Berlin and London (Baum+Whiteman, 2018). In addition, campaigns like 'Meatless Mondays' (which encourage people to go meatless one day a week) and 'Veganuary' (inspiring and supporting people to try becoming vegan for January, as a New Year's resolution) are targeted at the greater public. Hence, at first, it is the individual who follows a plant-based diet, but the collective dimension of empowerment plays an important role as well. Some scholars therefore recognise veganism as a social movement (le Grand, 2015).

The everyday practices of individuals following a plant-based diet are intertwined with the broader cultural transformation they wish to inspire. The empowerment of activists occurs by following, and experimenting with, a plant-based diet, understood as an alternative to established ways of food production and consumption. Living on a plant-based diet is not only about eating, but can also refer to lifestyle and ideology, as a way to man- 
ifest compassion and prosocial concerns, or as a form of resistance to the mainstream food culture in Western societies (Micheletti \& Stolle, 2012). Still, it can also be a practice that remains confined to the individual and thus lacks the supra-individual dimension, e.g., when the person is following a plant-based diet solely to improve personal health.

\subsection{Local Food Initiatives}

Before the emergence of supermarkets, people in both rural and urban contexts typically produced their own food or bought it from farmers' markets and local vendors. Over time, these practices were pushed to the side, severing the direct connections between producers and consumers (Grauerholz \& Owens, 2015; Perrett \& Jackson, 2015). Local food initiatives can be regarded as an attempt to restore these connections and establish new social, economic and physical ties against the practices of large-scale food production, which are regarded as destructive (Hinrichs, 2000; Lyson, 2004; see also Hasson, 2019; Prost, 2019). With the shared purpose of favouring local and seasonal over exotic and preserved foods (Hinrichs, 2000), local food initiatives manifest in numerous forms. A typical form is the farmers' market, where local small-scale producers sell their produce directly to consumers - a face-to-face interaction that takes place outside of the established mass food distribution system (Chiffoleau, Millet-Amrani, Rossi, Rivera-Ferre, \& Merino, 2019). A second example is CSA. Consumers typically purchase a membership and, in return, receive a 'share' of the farmer's seasonable yield. CSA is based on an agreement between local farmers and local consumers to share the costs, risks and products of the farm. The focus of CSA is clearly on community, going beyond a market relationship and, in this sense, representing a highly embedded agricultural market (Hinrichs, 2000). Further examples of local food initiatives include green box schemes, urban gardening, consumer cooperatives and artisanal foods.

The rise of local food initiatives can be interpreted as a counter-movement to the increasing globalisation of the food system, which leaves a massive environmental footprint and disconnects the consumer from foodrelated knowledge and the conditions under which food is produced (Grauerholz \& Owens, 2015). Local food initiatives represent venues for empowerment of local actors insofar as they are given the power to shape their own food environments rather than being dependent upon large corporations and international markets. Local producer-consumer relations are characterised by positive social ties and high social capital. Implying a local 'moral' economy that represents the antidote to a globalised market economy, in which only the economics of price count (Hinrichs, 2000, 2003), the consumers purchase local produce to support 'their' farmers, while local farmers provide pure, seasonal, healthy and transparent food. Local food initiatives thus involve a reciprocal empowerment relationship between producers and consumers. By offering locally produced food, producers assume the role of empowering subjects, as they create conditions that allow people to change their food shopping and consumption practices. At the same time, producers are empowered through consumers to actually engage in local food production.

Given the specific economic means of empowerment, which involve practices of selling and buying, this process of mutual empowerment does not always unfold evenly. In fact, local social relations are not immune to inequalities and uneven power structures. For example, farmers may move into new dependencies, especially those types of direct agricultural markets in which relations between consumers and producers are commodified (Hinrichs, 2000, p. 298). This is arguably different in other arrangements that involve relatively stable social ties between consumers and producers, some of which also directly involve consumers in the production process (such as CSAs). Consequently, spatial proximity might confer trust among the local population, but this is not guaranteed (Hinrichs, 2003). In addition, a local community typically mirrors the larger society, replicating or promoting new forms of social and economic exclusion and rendering the notion of the local community as a 'big family' an illusion. Accordingly, local food initiatives that initially intended to empower people by including them in an alternative system are regularly suspected of recreating the established food system or being subject to that system via the reproduction of its dominant economic logic (see also Perrett \& Jackson, 2015). Overall, while the 'local' in these examples is commonly associated with the good, whereas the 'global' represents the evil, some aspects might counter the simple local-global/good-bad dichotomy (Hinrichs, 2003). Essentially, these complexities make it difficult to assess the empowerment qualities of local food initiatives in an unequivocal manner.

\subsection{Food Policy Councils}

Food policy councils represent a type of institutionalised multi-stakeholder governance arrangement at the communal or regional level (Harper, Shattuck, Holt-Giménez, Alkon, \& Lambrick, 2009; see also Bassarab, Clark, Santo, \& Palmer, 2019; Sieveking, 2019). The first food councils were established in Canada and the US in the 1980s, and they have since spread to other countries all over the world. Food policy councils engage politically in the food system to improve food governance. Their emergence can be attributed to a critical reflection on contemporary food systems as being highly fragmented and therefore in need of better cooperation and coordination among involved actors (Harper et al., 2009). Generally, food policy councils seek improvement in various ways, such as by addressing the health-related consequences or sustainability of the food system. They do so by way of 'civic engagement into shaping public opinion, culture, institutions and policies by communication, lobbying and polit- 
ical activism' (Renting et al., 2012, p. 300). Towards this end, food policy councils typically gather and share information about the structure and functioning of a certain food system at the local or regional level; based on this, they advise policy-makers and political authorities, coordinate food-related actions among involved parties, and develop coordinated strategies to tackle problems in the food system.

Food policy councils can be initiated and institutionalised in different ways: They typically emerge from societal initiatives or movements, but they can also be initiated 'from above' by public authorities and policy-makers. Food policy councils reach out to key actors as well as experts on different aspects of the food system and develop models that are open to all interested people, both stakeholders and citizens alike. As a result, the composition of food policy councils varies, as do the processes of selecting the actors to involve (Gupta et al., 2018).

As such, food policy councils can be interpreted as a specific form of empowerment in the food sector. By bringing together actors involved in the food system, these councils render explicit and transparent the composition of the system and related power positions and relations. Empowerment occurs through the participation and representation in food policy councils of a wide range of actors, as diverse as 'anti-hunger and food justice advocates, educators...concerned citizens, government officials, farmers...food workers, business people, food processors and food distributors' (Harper et al., 2009 , p. 16), all of whom have a stake in food issues. Food policy councils have the potential to give voice to a whole range of views and positions, including those not yet represented in the food system. Empowerment also takes place through exchanges between the involved actors, including knowledge acquisition activities among the actors as well as the (collective) framing of problems and agenda setting. These councils seek to gain at least partial control over highly differentiated, sometimes scattered, food-related affairs, which are largely controlled by corporations (Welsh \& MacRae, 1998). Therefore, the institutionalisation of a food policy council can be regarded as an act of problematising the organisation and functioning of an existing food system. Finally, by involving various parties in one arena of interaction and communication, existing power positions and relations might be challenged and new ones might emerge. Food policy councils may thus serve as a venue for reshuffling existing power relations.

According to their mission, food policy councils must balance their members' interests with community interests and the broader political context. In particular, the levelling of citizen-led and government-led initiatives can be challenging. This points to a dilemma of 'institutionalised participation' in food policy councils: On the one hand, they create an arena for interaction and an environment for 'food citizenship' to develop (Welsh \& MacRae, 1998); on the other, they may be seen as mere vehicles for generating the legitimacy of official policies
(Rosol, 2012). Drawing the line between participation, as a form of empowerment, and the co-optation of stakeholders is not always an easy task.

\subsection{Government Food Education Policy}

Government policy is certainly not the most obvious thing that comes to mind when one thinks of empowerment. On the contrary, classical command-and-control policies (e.g., food safety regulations), economic incentives (e.g., 'fat taxes'), and also newer types of 'nudging' (such as food labels or food 'traffic light' ratings) are often under suspicion of infringing upon people's autonomy and approving rather than problematising established asymmetrical power relations between the state, food corporations and citizens (Gumbert, 2019; Mazzocchi et al., 2015). In fact, government policies addressing individual consumers are regularly criticised for violating the principle of consumer sovereignty (Korthals, 2001), hence disempowering and paternalizing individuals. Yet, some government policies are presented with the claim of empowering people. These include governmental health campaigns that inform people about healthy diets and the consequences of unhealthy eating (Israel, Checkoway, Schulz, \& Zimmerman, 2016). Prominent examples include '5-a-day' campaigns, which advise people to eat five portions of fruit and vegetables a day, as well as national dietary guidelines which aim to foster healthy eating habits and lifestyles (Fischer \& Garnett, 2016). Furthermore, food education programmes, such as school cooking, seek to motivate young people to acknowledge the significance of food and the food system more generally (Jones et al., 2012). Public-engagement campaigns drawing attention to food waste behaviour and its consequences are common in many European countries and beyond (Quested, Marsh, Stunell, \& Parry, 2013). All these programmes share the goal of informing and educating people about food issues. They aim to develop the individual's capability to change eating habits and make autonomous, responsible and prudent choices. In the broader sense, state education programmes can therefore be seen as a contribution to the formation of a food citizenship that encompasses judgement and action as well as commitment, duty and solidarity (Benn, 2004).

Attempts to empower people through government education are prima facie based on a mode of empowerment that presumes a relationship between two different kinds of actors. Acting as an empowerment subject, the government seeks to create capacities on the side of policy addressees (sometimes also addressed as collectives or milieus). The relevant means to do so is through 'education,' i.e., a diverse set of practices that seek to change people's attitudes and/or behaviour by conveying knowledge upon which people can base their food-related decisions. As the above examples suggest, different forms of information transfer accompany different degrees of empowerment. While the mere dis- 
semination of information in the form of food-related information campaigns can be considered a form of superficial empowerment (trusting in people's capacity to process this information), other forms aim to actively engage people in autonomous knowledge acquisition (e.g., school cooking). Finally, empowerment in the form of government education implies emergence from within the system, at least in the first place. Government education is not about encouraging people to exit the system, but instead familiarising them with the existing system so their voices can be heard. Yet, longer-term side effects may occur, especially from those forms of education that lead to changes in attitudes and the active acquisition of knowledge, both of which have the potential to transform policy addressees into food citizens who actively engage in the shaping of their food systems.

This overall positive assessment of empowerment through government education notwithstanding, numerous criticisms also exist. Among these are doubts as to whether, and to what extent, information-oriented policies can actually foster (enduring) changes in people's behaviours. Moreover, in a policy field that is deeply entwined with the lobbying interests of powerful agrocorporate actors, it can be questioned whether government education programmes are truly unbiased or concerned with empowering people (Teicholz, 2015). These programmes are sometimes considered merely as symbolic politics; or worse, as deliberate strategies to cover up, and thereby reaffirm, more fundamental power asymmetries in the food system. Government policies that seek to engage citizens are also suspected of (inadequately) shifting the responsibility from actors with 'real' power, such as food corporations, to individual citizenconsumers, who are neither responsible for the problems of the current food system nor in the position to really change anything (Lang et al., 2012). Consequently, the state becomes the protector of the powerful incumbent food regime.

\section{Democratic Potential of Food-Related Empowerment}

In this section, we further explore the forms of foodrelated empowerment with regard to their potential to improve the democratic quality of food systems. On the basis of the power-based concept of complex democracy developed in Section 2, we ask whether a certain form of food-related empowerment contributes to the development of one or more forms of political power related to the three dimensions of democracy. Accordingly, we consider empowerment as 'opening up' an existing political order insofar as it can be associated with the development of 'power to.' A practice of 'balancing out' existing asymmetries and inequalities is prevalent when we discern the development of 'power with.' Finally, we can speak of a democratic 'closing down' of a political order when there are indications that a certain empowerment practice creates 'power over.'

\subsection{Opening Up}

With regard to the input dimension of the democratic process, empowerment is directed towards developing 'power to.' This involves bringing people into positions to challenge the existing political order of a community, i.e., the established structures, norms, discourses and power relationships prevalent in that community. Accordingly, the 'opening' of an existing political order can take many forms, including the questioning of established problem framings, policy boundaries, resource allocation patterns and governance practices, or the problematisation of the legitimacy of incumbent actors and actor constellations as well as their orientations and strategies. On the basis of this understanding, the forms of food-related empowerment described above reveal different aspirations for a democratic 'opening.'

Most clearly pronounced are practices of 'empowering to' in local food initiatives. It is often their ambition to challenge the existing order of food systems and the roles and positions of incumbent actors. By emphasising 'local' autonomy (and identifying the local with the 'good'), these initiatives draw attention to the dominant practice of a 'globalised' (and, therefore, 'evil'), heteronomous system of food production, distribution and consumption (Hinrichs, 2003). Local food initiatives not only render visible and problematise the hidden structures, mechanisms and socio-ecological consequences of the global food regime, but they also offer alternative ideas and practices geared towards the transformation of this regime. As the initiatives provide ideas and infrastructures for approaching food differently, they constitute venues in which people can experience autonomy and self-reliance.

Although there are various reasons for following a plant-based diet, many of the related practices reveal considerable emancipatory claims. Especially when driven by environmental or ethical concerns, plant-based diets question and 'open up' normalities in the food system by calling for alternatives to established ideas and practices of 'good' food production and consumption. By promoting people's awareness about and ability to empower their food-related choices, these practices also involve the development of individual action capacity and autonomy in relation to food-related consumption patterns - with (more or less decidedly articulated) the hope for a transformation of the food system as a whole. Yet the system-related transformation potential of plantbased diets will depend on whether these practices assume the form of individual consumption decisions in the private sphere or are explicitly targeted at a broader community (e.g., vegan YouTube channels with tens of thousands of subscribers).

As compared to these two forms, the emancipatory empowerment potential of food policy councils seems less clearly pronounced. On the one hand, these councils can be interpreted as attempts to question the existing political order of the established food system. The 
very establishment of a food policy council can be seen as problematising the organisation and functioning of highly differentiated, sometimes fragmented food systems and their governance, making the composition of the system and the associated power positions and relationships explicit and transparent. Moreover, existing studies have shown that food policy councils bring actors into positions from which they can raise their voices against the existing food system order and formulate alternatives. In particular, open forms of food councils which, in addition to the usual suspects, also involve new actors have the potential to introduce alternative positions that are not yet represented in the food system. On the other hand, the challenging potential of food policy councils is limited when they are embedded in, or even initiated by, institutionalised food governance and actor arrangements. In particular, when set up 'officially' and in a 'top-down' manner, food policy councils are potentially closely linked to incumbent perspectives and practices of food governance. Their potential to develop alternatives would accordingly be limited to moderate visions which maintain compatibility with existing practices.

While food policy councils thus represent forms of 'caged' emancipatory empowerment, the potential of government education policy to develop people's capacities of 'power to' may be even more limited. The very fact that food policy councils refer to a form of external empowerment (by others) calls into question their autonomy-enhancing potential. In the same vein, many government education policies have the stated ambition of developing people's knowledge and skills in the field of food. But it is not always clear whether people could actually be brought into positions from which they could challenge existing food-related practices through the promotion of alternatives. For example, government education is often simply concerned with making people responsible (for their own diet) by informing them about 'good nutrition practices' as defined by experts. This puts people in a position of self-responsibility, but it does not automatically endow them with the skills and resources needed to live up to that responsibility, let alone to challenge the experts' and government's notion of good food. Despite these paternalistic implications, we know from other fields that government education policies may in the long run also raise people's awareness - and contribute to the development of citizenship (Dobson, 2003).

\subsection{Balancing Out}

With regard to the throughput dimension, a democratic form of empowerment is concerned with reshuffling and modifying an 'opened up' political order in such a way that prevailing asymmetries are levelled out (to some extent). This involves the cultivation of people's capacities 'to act together,' i.e., to engage in, shape and develop mutual exchange and cooperation. Such empowerment in the sense of 'empowering with' can take many forms, including bridging existing conflict lines and adopting cooperative action orientations; the willingness and ability to mobilise political support and form coalitions; and more discursive forms of valuing, engaging with and considering 'the other' by, for example, extending problem framings and goal orientations or reflecting a broader set of concerns.

The idea and practice of empowerment as enhancing people's capacities to act together appear to different degrees in the analysed forms of food-related empowerment, but they seem to be most clearly envisioned in food policy councils. These arrangements are meant to bring different actors together to discuss, deliberate and collaborate on the shaping of the food-related decisions of a political community-that is, establishing forms of 'power with' in food systems that would otherwise be very much characterised by individualised strategies and forms of action. Depending on how the councils are designed in terms of representation, they might also have the potential to bring actors into positions to voice, as well as listen to, previously unarticulated concerns. This might in turn relativize the position of existing powerful actors, allowing for the reshuffling, if not the outright levelling, of existing power relations in food governance.

Also, local food initiatives have considerable potential to develop 'power with.' This is reflected in, for example, their ambition to establish links between local producers and consumers. While these ties are rather loose and non-binding in the case of farmers' markets, CSAs are geared towards creating stronger forms of solidarity and collaborative orientations. By offering opportunities or even encouraging their members to participate in common activities - from agricultural work to participation in discussions and decision-making forums-CSAs can be seen as venues in which people actively develop collaborative skills.

Such cooperative empowerment practices appear to be less pronounced in other venues of food-related empowerment. With their rather individualistic orientation, plant-based diets, for example, tend at first to strengthen the individual's ability to make food-related decisions for themselves. Although they are partly linked to contexts characterised by a certain degree of interaction, they are not specifically geared towards creating 'collaborative' capacities. The same holds true for government food education. These empowerment practices are clearly aimed at individual actors to broaden their knowledge and reflections about food. But government education programmes are generally not about building capacity for joint action and are thus not concerned with developing forms of collective 'power-sharing.'

\subsection{Closing Down}

The democratic process is not only about 'opening up' and 'balancing out,' but also about 'closing down' a particular political order, at least temporarily. This output function is concerned with the creation of forms of 
agency related to the implementation and adoption of collectively binding courses of action and is therefore based on political 'power over.' Accordingly, the underlying empowerment involves the development of people's ability to recognise and acknowledge a form of noncoercive, yet binding, political authority. The development of 'power over' can take many forms, such as defining binding rules and responsibilities within a constellation or community of actors, resolving conflicts and recognising specific positions, creating common identities and values, and fostering ideas and knowledge that motivate, guide and inform collective action.

The potential of 'empowering over' seems to be most clearly pronounced in government education programmes. These forms of food-related empowerment can be seen as an attempt by a political community to develop itself through information and education. Although they do not establish binding rules, government education programmes aim to establish a common knowledge base and standards to influence and guide a society's food-related choices. In other contexts, government education is often seen as an important instrument of citizenship education in terms of developing the capacity to participate actively in political decision-making and with respect to communicating responsibilities, including the willingness to adhere to collectively defined societal values. This includes ideas of 'good,' 'healthy' or 'sustainable' food.

Still present but less pronounced is the potential for 'empowerment over' in food policy councils. These are indeed venues in which new coalitions of actors and joint strategies can emerge. However, to generate commitment among the actors to participate in joint courses of action will depend strongly on the concrete design and culture put into practice in a food policy council. Moreover, the potential to create collective commitment among external actors will depend strongly on the integration of food policy councils into the respective political-institutional context. Food policy councils are not always involved in the official policy process in such a way that they are in a position to shape the food policies of a political community in the sense of 'power over.'

Local food initiatives represent a similarly mixed case. On the one hand, they have the potential to establish new relations between different kinds of food actors and thereby create new forms of order and agency. Insofar as they provide spaces in which these actors can meet and exchange ideas, the initiatives foster the development of local food communities that gain collective agency to shape local food systems and beyond. However, as the venue for collective action is the market or networks outside the commonly acknowledged public sphere, there is limited potential to establish or reinvigorate forms of political 'power over' vis-à-vis the political community at large. Still, there are ways to opt out and withdraw from the 'power over' established in these governance arrangements. The same is true for plant-based diets. Although these forms of empowerment may bring people into positions of agency, they do not constitute a kind of collective agency that can enable such people to settle conflicts and resolve problems, or to allocate and redistribute resources in a collectively binding manner.

Overall, our tentative assessment (see Table 2 ) indicates that the different forms of food-related empowerment we analysed exhibit different democratic potentials. More specifically, we find that different empowerment venues are geared towards the development of different types of power. While some seem to have their strengths in opening up power relations by promoting emancipatory forms of 'power to,' other venues appear to foster the capabilities of actors to collaborate and deliberate on food-related issues, i.e., 'power with.' Still other venues are more about 'closing' and establishing collective agency by developing food-related 'power over.' Against the backdrop of our notion of power-based complex democracy, these different types of power correspond with different functions of the democratic process. This suggests that there is no one form of democratic empowerment, but instead different forms with different and complementary democratic potentials. From that perspective, the challenge of democratising the food system lies in linking different empowerment venues in ways that, together, can form functioning configurations of complex democratic governance.

\section{Conclusion}

Starting from the observation of a considerable power concentration in the food system and the subsequent emergence of various venues and practices to engage people in dealing with food issues, we analysed the democratic potential of characteristic forms of foodrelated empowerment. Our analysis was based on a concept of democratic empowerment that combines a broad analytical understanding of empowerment with a power-

Table 2. Tentative assessment of democratic potentials of food-related empowerment forms.

\begin{tabular}{lccc}
\hline & Opening Up & Balancing Out & Closing Down \\
\hline Plant-Based Diets & + & 0 & - \\
\hline Local Food Initiatives & + & $+/ 0$ & 0 \\
\hline Food Policy Councils & 0 & + & $0 /+$ \\
\hline Government Education & $0 /-$ & - & + \\
\hline
\end{tabular}


based notion of complex democracy. From this perspective, democracy appears as a configuration or sequence of 'power to,' 'power with' and 'power over,' each of which presupposes a specific form of empowerment.

Our preliminary analysis of four typical venues where people deal with food issues revealed both similarities and differences between them, leading to a more comprehensive picture of these often separately analysed manifestations of food politics. Specifically, our preliminary observations suggest that different venues exhibit different forms of empowerment. The analysis also suggests that different food-related forms of empowerment have different democratic potentials. As they target the development of different types of power, they relate to different functions of a complex democracy.

What are the general implications of our findings for the understanding of food democracy and the democratisation of the food system? Two points stand out in particular. First, venues where people deal with food issues might have the potential to democratise the food system. More specifically, different forms of food-related empowerment have different democratic potentials, i.e., potentials to promote different forms of power corresponding with different functions of the democratic process. However, based on our analysis, we can only identify a potential, but cannot say anything about the actual impacts and their magnitude. Whether and to what extent these venues are actually capable of unfolding their potential is thus an open question.

Second, the analysis of various forms of food-related empowerment through a power-based concept of complex democracy suggests that there is not a single 'golden' path to a democratic food system. Food democracy should be seen as the complex interplay of various forms of political power, which involve different kinds of empowerment practices. For a democratisation of the food system, it would thus be misleading to rely solely on practices of 'empowerment to' and/or 'empowerment with,' as large parts of the food democracy discourse seem to suggest (see Bornemann \& Weiland, 2019). These practices play an important role in the democratic process as they serve to open up and balance out existing power relations in the food system. However, they are not sufficient. Food democracy also requires forms of 'power over' in order to make collectively binding decisions possible. A comprehensive democratisation of the food system in an increasingly pluralised governance context, therefore, requires the combination of all three types of empowerment to establish the basis for the complex democratic interplay between 'power to,' 'power with' and 'power over.'

Based on our study, we see several promising avenues for future research. First, more theoretical work is needed to situate and anchor the power-based concept of complex democracy in current normative and positive democracy theory. Such a theoretical investigation must further substantiate that a power-based concept of complex democracy is an appropriate way to analyse democratisation processes in increasingly complex, plu$\mathrm{ral}$, and decentralised governance systems. In empirical terms, we see the need for more detailed and focused analysis of concrete cases of food-related empowerment. Such analyses should focus not only on democratisation potential, but also on whether and how this potential is unfolding on the ground. This could also bring mechanisms into view that involve other empowerment dimensions, such as the actors and contexts of empowerment (see Section 2). One question is, for example, what effects the empowerment of individuals vis-à-vis collectives has on the democratising role of empowerment. In addition, more detailed, contextualised analyses can reveal whether and to what extent different forms of democratic empowerment correspond with the democratic expectations and perceptions of the involved actors. More theoretical and empirical attention should also be given to the potential side effects of empowerment practices. For example, it should be analysed where the theoretical and empirical limits of empowerment and possible tipping points to forms of 'responsibilisation' lie.

This points to the more general question of how different venues and practices of food-related empowerment interact in real-world governance contexts. Such analyses could not only shed light on the aggregated effects of different empowerment forms on the democratic quality of specific local food systems. They could also reveal (meta-)governance arrangements that in some way relate different complementary forms of foodrelated empowerment to one another and point to potentials for the strategic shaping of these arrangements by state and non-state actors towards democracy. Finally, on the basis of more comprehensive assessments of the democratic effects of empowerment, the consequences for a sustainability transformation of the food system can be examined (Lohest, Bauler, Sureau, van Mol, \& Achten, 2019). Research can show whether empowerment can actually be seen not only as a means of democratisation, but also as a mechanism for the sustainable transformation of the food system, i.e., as the key to a democratic and sustainable food system.

\section{Acknowledgments}

We would like to thank two anonymous reviewers and the journal editor for their useful feedback on an earlier version of this article.

\section{Conflict of Interests}

The authors declare no conflict of interests.

\section{References}

Alkon, A. H., \& Guthman, J. (Eds.). (2017). The new food activism: Opposition, cooperation, and collective action. Oakland, CA: University of California Press.

Allen, A. (1998). Rethinking power. Hypatia, 13(1), 21-40. 
https://doi.org/10.1111/j.1527-2001.1998.tb01350

Allen, A. (2008). Power and the politics of difference: Oppression, empowerment, and transnational justice. Hypatia, 23(3), 156-172. https://doi.org/10.1111/j. 1527-2001.2008.tb01210.x

Andersen, J., \& Siim, B. (2004). Introduction: The politics of inclusion and empowerment-Gender, class and citizenship. In J. Andersen \& B. Siim (Eds.), Politics of inclusion and empowerment: Gender, class and citizenship (pp. 1-18). Houndmills, Basingstoke and Hampshire: Palgrave Macmillan.

Avelino, F. (2017). Power in sustainability transitions: Analysing power and (dis)empowerment in transformative change towards sustainability. Environmental Policy and Governance, 27(6), 505-520. https:// doi.org/10.1002/eet.1777

Barber, B. R. (1984). Strong democracy: Participatory politics for a new age. Berkeley, CA: University of California Press.

Bassarab, K., Clark, J. K., Santo, R., \& Palmer, A. (2019). Finding our way to food democracy: Lessons from US food policy council governance. Politics and Governance, 7(4), 32-47.

Baum+Whiteman. (2018). Consultants predict 11 hottest food \& beverage trends in restaurant \& hotel dining for 2018. Brookly, NY: Baum+Whiteman. Retrieved from https://docs.wixstatic.com/ugd/0c5d00_90935 d6fda344991a8fc2452eb112c83.pdf

Behringer, J., \& Feindt, P. H. (2019). How shall we judge agri-food governance? Legitimacy constructions in food democracy and co-regulation discourses. Politics and Governance, 7(4), 119-130.

Beitz, C. R. (1989). Political equality: An essay in democratic theory. Princeton, NJ: Princeton University Press.

Benn, J. (2004). Consumer education between 'consumership' and citizenship: Experiences from studies of young people. International Journal of Consumer Studies, 28(2), 108-116. https://doi.org/10. 1111/j.1470-6431.2003.00364.x

Bornemann, B. (2017). Private participation going public? Interpreting the nexus between design, frames, roles, and context of the fracking 'InfoDialog' in Germany. Journal of Environmental Policy \& Planning, 19(1), 89-108. https://doi.org/10.1080/1523908X. 2016.1138401

Bornemann, B., \& Haus, M. (2017). Post-democracy or post-liberal democracy? Reassessing participation from an advanced governance perspective. Paper presented at the International Research Workshop on "Activation-Self-Management-Overload. Political Participation beyond the Post-democratic Turn," Institute for Social Change and Sustainability, University of Economics and Business, Vienna, Austria.

Bornemann, B., Weiland, S. (2019). Editorial: New perspectives on food democracy. Politics and Governance, $7(4), 1-7$.

Cherry, E. (2014). Vegetarianism and veganism. In C. J. Forsyth \& H. Copes (Eds.), Encyclopedia of social de- viance (pp. 771-773). Thousand Oaks, CA: Sage.

Chiffoleau, Y., Millet-Amrani, S., Rossi, A., Rivera-Ferre, M. G., \& Merino, P. L. (2019). The participatory construction of new economic models in short food supply chains. Journal of Rural Studies, 68, 182-190. https://doi.org/10.1016/j.jurstud.2019.01.019

Daugbjerg, C., \& Feindt, P. H. (2017). Post-exceptionalism in public policy: Transforming food and agricultural policy. Journal of European Public Policy, 24(11), 1565-1584. https://doi.org/10.1080/13501763. 2017.1334081

Dobson, A. (2003). Citizenship and the environment. Oxford: Oxford University Press.

Dryzek, J. S. (2000). Deliberative democracy and beyond: Liberals, critics, contestations. Oxford and New York, NY: Oxford University Press.

Fernandez-Wulff, P. (2019). Collective agency in the making: How social innovations in the food system practice democracy beyond consumption. Politics and Governance, 7(4), 81-93.

Fischer, C. G., \& Garnett, T. (2016). Plates, pyramids, planet. Developments in national healthy and sustainable dietary guidelines: A state of play assessment. Rome and Oxford: Food and Agriculture Organization of the United Nations and The Food Climate Research Network. Retrieved from http://www.fao. org/3/i5640e/15640E.pdf

Grauerholz, L., \& Owens, N. (2015). Alternative food movements. In J. D. Wright (Ed.), International encyclopedia of the social \& behavioral sciences (2nd ed., pp. 566-572). Oxford: Elsevier. https://doi.org/ 10.1016/B978-0-08-097086-8.64133-8

Gumbert, T. (2019). Anti-democratic tenets? Behavioural-economic imaginaries of a future food system. Politics and Governance, 7(4), 94-104.

Gupta, C., Campbell, D., Munden-Dixon, K., Sowerwine, J., Capps, S., Feenstra, G., \& van Soelen Kim, J. (2018). Food policy councils and local governments: Creating effective collaboration for food systems change. Journal of Agriculture, Food Systems, and Community Development, 8(B), 11-28. https://doi.org/10.5304/ jafscd.2018.08B.006

Harper, A., Shattuck, A., Holt-Giménez, E., Alkon, A., \& Lambrick, F. (2009). Food policy councils: Lessons learned. Oakland, CA: Institute for Food and Development Policy. Retrieved from http://www. farmlandinfo.org/sites/default/files/Food_Policy_ Councils_1.pdf

Hassanein, N. (2003). Practicing food democracy: A pragmatic politics of transformation. Journal of Rural Studies, 19(1), 77-86. https://doi.org/10.1016/ S0743-0167(02)00041-4

Hasson, A. (2019). Building London's Food Democracy: Using a political space framework to assess the contributions of urban agriculture to local food decisionmaking. Politics and Governance, 7(4), 154-164.

Haugaard, M. (2010). Democracy, political power, and authority. Social Research, 77(4), 1049-1074. Re- 
trieved from http://www.jstor.org/stable/23347119

Haugaard, M. (2015). Concerted power over. Constellations, 22(1), 147-158. https://doi.org/10.1111/14678675.12146

Hendriks, C. M. (2009). Deliberative governance in the context of power. Policy and Society, 28(3), 173-184. https://doi.org/10.1016/j.polsoc.2009.08.004

Hinrichs, C. C. (2000). Embeddedness and local food systems: Notes on two types of direct agricultural market. Journal of Rural Studies, 16(3), 295-303. https:// doi.org/10.1016/S0743-0167(99)00063-7

Hinrichs, C. C. (2003). The practice and politics of food system localization. Journal of Rural Studies, 19(1), 33-45. https://doi.org/10.1016/S07430167(02)00040-2

International Food Policy Research Institute. (2016). Global nutrition report 2016: From promise to impact-Ending malnutrition by 2030. Washington, DC: International Food Policy Research Institute.

Israel, B. A., Checkoway, B., Schulz, A., \& Zimmerman, M. (2016). Health education and community empowerment: Conceptualizing and measuring perceptions of individual, organizational, and community control. Health Education Quarterly, 21(2), 149-170. https:// doi.org/10.1177/109019819402100203

Jones, M., Dailami, N., Weitkamp, E., Salmon, D., Kimberlee, R., Morley, A., \& Orme, J. (2012). Food sustainability education as a route to healthier eating: Evaluation of a multi-component school programme in English primary schools. Health Education Research, 27(3), 448-458. https://doi.org/10.1093/her/cys016

Korthals, M. (2001). Taking consumers seriously: Two concepts of consumer sovereignty. Journal of Agricultural and Environmental Ethics, 14(2), 201-215. https://doi.org/10.1023/A:1011356930245

Lacy, W. B. (2000). Empowering communities through public work, science, and local food systems: Revisiting democracy and globalization. Rural Sociology, 65(1), 3-26. https://doi.org/10.1111/j.15490831.2000.tb00340.x

Lang, T., Barling, D., \& Caraher, M. (2012). Food policy: Integrating health, environment and society. New York, NY: Oxford University Press.

le Grand, Y. (2015). Activism through commensality: Food and politics in a temporary vegan zone. In S. Kerner, C. Chou, \& M. Warmind (Eds.), Commensality (pp. 51-64). London: Bloomsbury Academic. https:// doi.org/10.5040/9781474245326.ch-005

Lohest, F., Bauler, T., Sureau, S., van Mol, J., \& Achten, W. (2019). Linking food democracy and sustainability on the ground: Learnings from the study of three alternative food networks in Brussels. Politics and Governance, 7(4), 21-31.

Lyson, T. A. (2004). Civic agriculture: Reconnecting farm, food, and community. Medford, MA: Tufts University Press.

Mazzocchi, M., Cagnone, S., Bech-Larsen, T., Niedźwiedzka, B., Saba, A., Shankar, B., . . . Traill, W. B. (2015).
What is the public appetite for healthy eating policies? Evidence from a cross-European survey. Health Economics, Policy, and Law, 10(3), 267-292. https:// doi.org/10.1017/S1744133114000346

McLaughlin, K. (2016). Empowerment: A critique. London: Routledge.

McMichael, P. (2013). Food regimes and agrarian questions. Rugby: Practical Action.

Micheletti, M., \& Stolle, D. (2012). Vegetarianism: A lifestyle politics? In M. Micheletti \& A. S. McFarland (Eds.), Creative participation: Responsibility-taking in the political world (pp. 127-147). Boulder, CO: Paradigm.

Moore, K., \& Swisher, M. (2015). The food movement: Growing white privilege, diversity, or empowerment? Journal of Agriculture, Food Systems, and Community Development, 5(4), 115-119. https://doi. org/10.5304/jafscd.2015.054.013

Mouffe, C. (2000). The democratic paradox. London: Verso.

Partzsch, L. (2017). 'Power with' and 'power to' in environmental politics and the transition to sustainability. Environmental Politics, 26(2), 193-211. https:// doi.org/10.1080/09644016.2016.1256961

Perrett, A., \& Jackson, C. (2015). Local food, food democracy, and food hubs. Journal of Agriculture, Food Systems, and Community Development, 6(1), 7-18. https://doi.org/10.5304/jafscd.2015.061.003

Petetin, L. (2016). Food democracy in food systems. In P. B. Thompson \& D. M. Kaplan (Eds.), Encyclopedia of food and agricultural ethics (Vol. 6, pp. 1-7). Dordrecht: Springer Netherlands. https://doi.org/10. 1007/978-94-007-6167-4_548-1

Prost, S. (2019). Food democracy for all? Developing a food hub in the context of socio-economic deprivation. Politics and Governance, 7(4), 142-153.

Quested, T. E., Marsh, E., Stunell, D., \& Parry, A. D. (2013), Spaghetti soup: The complex world of food waste behaviours. Resources, Conservation and Recycling, 79, 43-51. https://doi.org/10.1016/j.resconrec.2013.04. 011

Renting, H., Schermer, M., \& Rossi, A. (2012). Building food democracy: Exploring civic food networks and newly emerging forms of food citizenship. International Journal of Sociology of Agriculture and Food, 19(3), 289-307.

Rosol, M. (2012). Community volunteering as neoliberal strategy? Green space production in Berlin. Antipode, 44(1), 239-257. https://doi.org/10.1111/ j.1467-8330.2011.00861.x

Schmidt, V. A. (2013). Democracy and legitimacy in the European Union revisited: Input, output and 'throughput.' Political Studies, 61(1), 2-22. https:// doi.org/10.1111/j.1467-9248.2012.00962.x

Sieveking, A. (2019). Food policy councils as loci for practicing food democracy? Insights from the case of Oldenburg, Germany. Politics and Governance, 7(4), 48-58. 
Skogstad, G. (1998). Ideas, paradigms, and institutions: Agricultural exceptionalism in the European Union and in the United States. Governance: An International Journal of Policy and Administration, 11(4), 463-490.

Sørensen, E. (1997). Democracy and empowerment. Public Administration, 75(3), 553-567. https://doi.org/ 10.1111/1467-9299.00074

Sørensen, E., \& Torfing, J. (2005). Network governance and post-liberal democracy. Administrative Theory \& Praxis, 27(2), 197-237. https://doi.org/10.1080/ 10841806.2005.11029489

Teicholz, N. (2015). The scientific report guiding the US dietary guidelines: Is it scientific? BMJ (Clinical Research Ed.), 351, h4962. https://doi.org/10.1136/ bmj.h4962

Tornaghi, C. (2017). Urban agriculture in the food- disabling city: (Re)defining urban food justice, reimagining a politics of empowerment. Antipode, 49(3), 781-801. https://doi.org/10.1111/anti.12291

Tracy, M. (1989). Government and agriculture in Western Europe 1880-1988. Hemel Hempstead: Harvester Wheatsheaf.

Welsh, J., \& MacRae, R. (1998). Food citizenship and community food security: Lessons from Toronto, Canada. Canadian Journal of Development Studies/Revue Canadienne D'études du Développement, 19(4), 237-255. https://doi.org/10.1080/02255189. 1998.9669786

Welzel, C. (2013). Freedom rising: Human empowerment and the quest for emancipation. Cambridge: Cambridge University Press.

Young, I. M. (1990). Justice and the politics of difference. Princeton, NJ: Princeton University Press.

\section{About the Authors}

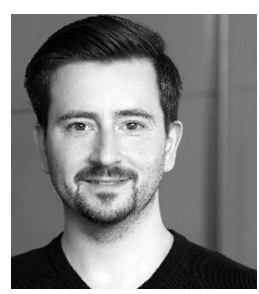

Basil Bornemann is a Post-Doctoral Researcher and Lecturer at the Sustainability Research Group, University of Basel. He has an interdisciplinary study background in environmental sciences and holds a doctoral degree in political science. His research focuses on sustainability-oriented governance transformations and their democratic implications in different fields of study, such as energy and food. He is further interested in principles and practices of transformative sustainability science.

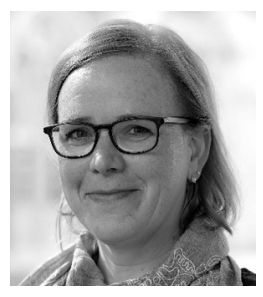

Sabine Weiland is Associate Professor of political science at Lille Catholic University, affiliated with the European School of Political and Social Sciences. She is the Director of the ESPOL-LAB Research Centre for European and International Politics, and the Head of the MA Food Politics programme. Her research interests are in food politics, environmental governance, reflexive governance, and sustainable development and transformation. 